\title{
Ebavõrdne võitlus stand-upi ja kabareetraditsiooni vahel Poolas
}

\author{
Władysław Chłopicki
}

Teesid: Käesolev artikkel kirjeldab püstijalakomöödia traditsiooni ja selle tausta Poolas, alustades kabaree- ja teatrigruppidest, mis töötasid Poola linnades 20. sajandi alguses. Seejärel vaadeldakse kaasaegse stand-upi variatsioone, käsitledes eelkõige viimase kahekümne aasta jooksul esile kerkinud trende nii televisioonis kui ka arvukates komöödiaklubides, otsides paralleele vanema materjaliga.

Üks traditsioonilistest komöödiažanritest, millel on sarnaseid jooni standupiga, on monoloog. Selle žanri põhiolemus on kirjanduslik, raskestimõistetav, jutustav; esineja ei riietunud kostüümi, ei kasutanud laval rekvisiite ega laulnud. Monoloogi etendaja rääkis oma kogemustest publikuga kontakti otsimata ning (mis on kaunis oluline) slängiväljendeid ja tänavakeelt (nt vägisõnu), kasutamata.

Viimase kahekümne aasta jooksul on Poolas aeglaselt kanda kinnitanud ameerikapärane stand-up. Selle tunnusjooneks on just tänavakeele ja slängi kasutamine, ning ka teemade hulgas on eelkõige need, millest varasemas monoloogi-etenduses hoiduti. Noored esinejad, kes seda stiili järgivad, leidsid omale väljundi HBO püstijalatelesaates "Na stojaka" (Püsti seistes), mis on praeguseks jooksnud juba kümme aastat, aga populaarne on ka püstijalakoomikute võistlus "Zabij mnie Smiechem" (Naeruta mind surnuks), mis jookseb Polsati kanalil alates aastast 2010. Viimase auhinnaks on reis Ameerika Ühendriikidesse stand-upi kooli. Selline stiil pole aga kõikidele vastuvõetav. Sellele viitab ka üks internetikommentaar, mis võtab toimuva kokku ühe sõnaga: stand-up-tragöödia. Poola publik hindab komöödiaetendustes eelkõige naljakust ja alles seejärel obstsöönsust, samas rõhuvad mõned noortest esinejatest ainult viimasele ja unustavad oma esmase eesmärgi, milleks on kuulajate lõbustamine.

Märksõnad: kabaree, monoloog, poola huumor, stand-up

\section{Varajane stand-up: kabareekultuur ja monoloogid}

Poola lavakomöödia ulatub 18. sajandisse, kui näitekirjanikud Wojciech Bogusławski ja veidi hiljem Aleksander Fredro kirjutasid ja lavastasid oma esimesed sotsiaalsed kombekomöödiad (vt Wojtak 2012). Sellele järgnes kabareetraditsiooni sünd ja areng 20. sajandi alguses, kui Noor-Poola liikumine 
toetas boheemlike ringkondade tegevust, kes seda žanrit kõrgelt hindasid. Enne Esimest maailmasõda õitses mitmel pool Poolas ka iseseisvumisliikumine, eriti Galiitsias, mille olid okupeerinud Austria väed. Sellele aitas kaasa piirkonna piisav autonoomsus ja Austria võimuladviku ükskõiksus Galiitsias toimuva suhtes. Eriti suurt vabadust nautisid Krakovi tolleaegsed elanikud - Krakov oli tuntud kui kunstnike ja intelligentide elu- ja tegutsemispaik, kus peeti lugu prantsuse kultuurist, ning seetõttu pole imestada, et just seal sai alguse Poola kabareetraditsioon. Tuleks kohe rõhutada, et prantsuse kabaree kohanes Poola lavadel kohalike vajadustega ning selle põhijooneks oli etteastete peenekoelisus. Seda peeti kõrgelennuliseks, haritud publikule mõeldud meelelahutuseks, mis põhines hinnatud kirjandustekstidel, draamatükkidel või sketšidel, kuhu oli lisatud laule ja monolooge. Tulemuseks olid lühikesed, temaatilised etendused, kus üks esineja esitas varem ette valmistatud ja hoolikalt selgeks õpitud teksti.

Esimene kabaree avati Krakovis 1905. aastal ning selle nimeks sai Zielony Balonik (Väike Roheline Õhupall). Seal toimusid regulaarsed kabareeõhtud kuni 1911. aastani. Kabareelokaal kuulus Michaliki pirukakohviku omanikule ning see asus Krakovi vanalinnas Florianska tänaval. Praeguseni autentsena säilinud lokaal on nüüd avatud kohvikuna, mille nimeks on Jama Michalika. Kabareed sai külastada ainult kutsetega, mistõttu publik koosnes valitud eliidist ja sissepääs kabareeõhtutele osutus staatusesümboliks. Krakovi keskklassi hulgas muutusid kutsed üliväärtuslikuks ihaldusobjektiks. Iga õhtu oli kordumatu esietendus. Peagi hakkasid linnas levima kuulujutud, milles kirjeldati kirgastes värvides väidetavalt kabarees valitsevat liiderlikkust, orgiaid ja alasti tantsimisi, mis omakorda pani aluse selle koha pahelisele mainele (Kiec 2004: 17). Seal tulid esitamisele mitmest žanrist etteasted: lavalt võis kuulda luuletusi, laule, paroodiaid, huumorisketše. Esialgu oli üritustes tunda spontaansust, kuid hiljem toimus kõik paika pandud mängukava alusel. Kabaree põhifookuseks oli sotsiaalne satiir, mis sihtis kriitikanooli avaliku elu tegelaste suunas, kuigi poliitilisi teemasid ei puudutatud. See on üsna mõistetav olukorras, kus võõrvõimud olid ala okupeerinud ja vähemalt teoreetiliselt valitses poliitiline tsensuur. Iga kabareeõhtu naelaks kujunesid õhtujuhi Jan Kisielewski hoolikalt ettevalmistatud solvangud, milles ta pöördus isiklikult kõikide esmakordselt kohal viibivate inimeste poole. See tähendas omamoodi initsiatsiooniriitust, mille pidid läbi tegema kõik uustulnukad. Kirjanik Tadeusz Boy Żeleński jagab oma muljeid 7. oktoobril 1905 toimunud etenduse kohta:

Sellel meeldejääval õhtul astus lavale teadustaja, seljas frakk, valged säärised, ja alustas avakõnet, mis oli pooleldi poola-, pooleldi ingliskeelne. Ta nimetas publikut elajateks, käitudes nagu tõeline kunstnik karja väikekodanlike, kitsarinnaliste kultuurivaenulike, rutiini armastavate filistrite ees. Tegelikult oli ruum täis pigem kunstihuvilisi boheemlasi; ja 
peagi selgus ka, et teadustaja oli läbi imbunud mitte peenest veinist, vaid labasest viinast. Seejärel muutus ta fü̈̈siliseks, võideldes paljaste kätega "paksukssöödetud keskklassi” vastu, keda tema jaoks kehastas suurt kasvu kunstnik Stanistawski. See heasüdamlik hiiglane tegi ründaja relvituks ning too saadeti peatäit välja magama, mistõttu värske kabaree jäi teadustajata. Ülejäänud ôhtut täitsid improvisatsioonid, joomalaulud ja muidugi rohke joomine. (Kiec 2004: 13; toimetaja tõlge inglise keelest.)

Kabaree Väike Roheline Õhupall pani aluse viljakale traditsioonile. Üsna pea pärast selle avamist, iseäranis arvukalt pärast Poola iseseisvumist 1918. aastal, hakkas nii Krakovis kui ka teistes linnades tekkima juurde uusi kabareelokaale. Üks tähelepanuväärsemaid oli koht nimega Qui pro Quo, mis töötas Varssavis aastatel 1919-1931. Ka see oli peamiselt kirjanduslik kabaree, kus sotsiaalne ja poliitiline satiir, mis oli sel ajal juba lubatud, segunes luuletuste ja lauludega. Mõnede viimaste autoriks oli Julian Tuwim, kuulus juudist poeet, kes tundis väga hästi poola kultuuri ja on siiani üks enim armastatud poola poeetidest 20. sajandil. Sealse kabaree spetsialiteediks peeti aga žanrit, mida nimetati szmonces (jidiši keeles 'absurd'), aga tuntud oli ka szlagier (samuti jidišikeelne sõna, mille eestikeelne vaste oleks 'šlaager').

Ka Krakovis oli kabareekultuur saavutanud selleks ajaks kõrghetke, ja see jätkus kahe maailmasõja vahel ning hiljem, 1950. aastatel, kui järjekordne kuulus kabaree nimega Piwnica pod Baranami (Kelder Jäärade All, nimetus tulenes selle asukohast endise palee keldrites, mille omanikuks oli kunagi aristrokraatlik Potockide perekond, ja mida tunti hüüdnimega "Jäärade all", sest selle karniisi kaunistasid jäärapeade skulptuurid). Selle rajas 1956. aastal legendaarne Piotr Skrzynecki, tudeng, kes saabus Krakovisse Łódźist, armus sellesse linna ja asus sinna elama. Ta oli tuntud kui tõeline boheem, kes toitus ja elaski üksnes kirjandusest ja alkoholist ning kellel puudus kindel elukoht, mistõttu oli ta alailma vastuolus võimudega. Sellegipoolest anti talle luba avada kabaree, ning selle sammu tõenäolisimaks põhjenduseks oli kommunistliku võimuladviku soov demonstreerida avatust muutustele. Sula, mis järgnes Stalini surmale 1953. aastal, andis seega elu ka sellele kuulsale kabareele. Kabaree töötas kuni aastani 1997, mil Piotr Skrzynecki suri, aga tema kaastöötajad ja sõbrad jätkavad tema rajatud lokaali pidamist. Regulaarsed kabareeõhtud, mis koosnevad peamiselt lauludest, toimuvad selles lokaalis tänase päevani. Nagu Väikese Rohelise Õhupalli kabareesse, nii sai ka lokaali Kelder Jäärade All üksnes kutsetega, mida võib hästi mõista kabaree algusaastatel valitsenud poliitilise tsensuuri õhustikku arvestades. Loomulikult mõjus see publikule samamoodi kui varasem eksperiment Väikeses Rohelises Õhupallis aastal 1905: kõik tahtsid olla kutsutud, sest see oli staatuse sümboliks tolleaegses ülikorralikus ja konservatiivses Krakovis. Iga uus etendus pakkus jutuainet 
linna kuluaarides, kuid ainult need, kes päriselt kohal olid viibinud, teadsid kogu tõde. Kabareepidajate teadlikuks strateegiaks oli tugevdada siseringi ühtsust, ning kahtlemata muutis see kutsutud külaliste hinnangu etteastetele veelgi positiivsemaks (vt ka Lockyer \& Myers 2011). Kelder Jäärade All saavutas sellise kuulsuse ja mõjuvõimu, et aastal 1989 andsid sealsed näitlejad külalisetendusi suurtel lavadel ja astusid üles ka televisioonis. Kabarees võis näha laule ja sketše (nt http://www.youtube.com/watch?v=frg0sSCUEFg), millest igaühe juhatas sisse Piotr Skrzynecki õhtujuhina isiklikult, olles alati varustatud oma lahutamatu kellukesega. Seda hoidis ta käes, et anda märku ühe numbri lõppemisest ja teise algusest. Mõnikord, kui ta lavale hiljaks jäi, kuuldi saalivaikuses kaugelt keldrist või lavatagustest ruumidest kostvat kellahelinat juba enne, kui ta lõõtsutavana lavale ilmus, ja see põhjustas alati publiku naerupahvakuid.

Vaatamata tsensuurile ei hoidunud näitlejad poliitilisest satiirist, kuid nad esitasid seda nii intelligentselt, et valvsad tsensorid ei tabanudki diversiooni ära. Üks traditsioonilistest vormidest oli paroodia. Neist kuulsaim oli etteaste, kus parodeeriti bürokraatiat, lauldes ametlike dokumentide viisistatud tekste. Ühes variatsioonis sai Piotr Skrzynecki kohalikust politseijaoskonnast kirja, milles tal paluti maksta trahvi selle eest, et ta oli tabatud öösel linna peal uitamas, pargipingil magamas, ning politseile obstsöönsusi karjumas. Laulja, kes seda paroodiat esitas, kandis ilmekalt ette dokumentide tekste, mis oli täis sel ajal iseloomulikku kantseliiti, ja tsiteeris peast seadusi. Tema etteastes polnud midagi ebaseaduslikku, ja tsensoritel polnud kusagilt kinni haarata ega õigust paroodiat ära keelata. Teine tavaline osa kabareeõhtust Keldris Jäärade All oli Piotr Skrzynecki komme kutsuda kohale erilisi külalisi - tuntud avaliku elu tegelasi, sh tuntud poliitikuid - ning paluda nad endaga koos lavale, kostitades neid leebe pilkega, mida nad hiljem suure uhkusega meenutasid.

Poola kabareekultuuris oli ka teine suund, mis arenes 1960. ja 1970. aastatel, mille eredaim näide oli Kabaret Starszych Panów (Eakate Härrade Kabaree). See oli ainus kabaree, mis aeg-ajalt leidis tee ka teleekraanile. Loomulikult oli see täiesti apoliitiline, aga selle retrohõnguline õhustik ja artistide vanamoeline riietumisstiil (kus olid aukohal kõvakübarad ja sabakuued) andis juba iseenesest selge sõnumi - sellega sooviti vastanduda valitsevale töölisklassi võimule, nn proletariaadi diktatuurile, mille eredaimaks väljenduseks oli kommunistlike kaaskodanike hoolimatus või isegi vastumeelsus sõjaeelse aristokraatliku ja intellektuaalse meelelahutuse vastu. Kabarees esitati peenelt ülesehitatud monolooge ja sketše ning laule (vt http://www.youtube.com/ watch?v=prAtqmW7EVY). Nendes absurdi kalduvates etendustes, kus repertuaari muutsid vaheldusrikkamaks meeldejääva meloodiaga laulukesed, puudus poliitiline sõnum. Etteasted olid pikitud maheda sotsiaalse satiiriga ning 
see pakkus publikule just seda, mida sel hetkel kõige rohkem vaja: võimalust distantseeruda ümbritsevast depressiivsest reaalsusest.

Qui pro Quos enne Teist maailmasõda tuntuks mängitud nö monoloogi-stiili praktiseerisid 1960. aastatest 1980. aastateni Tey Cabaret Poznańis ja Dudek (Vainukägu) Varssavis. Esinejad tulid nendes klubides lavale üksi ja esitasid ettevalmistatud monoloogi, mis võis, aga ei pruukinud olla ilukirjanduslik, kuigi selle stiil oli alati väljapeetud ja keelekasutus viisakas. Vulgaarsustel polnud lavalaudadel kohta. Esimeses neist kasutas vaid üks esineja, kelle lavakarakteriks oli töölisklassi kuuluv mees, mõõdukalt vägisõnu. Suurema väljendusvabaduse poolest oli tuntud ka kabaree Pod Egidą Varssavis, seal esitatavad monoloogid pakkusid kuulajatele pinget oma sageli seksuaalse alatooniga ning sõnaliste etteastete vahel lõbustati publikut mõnikord striptiisiga. Üks kuulsamaid monolooge, mida esitati nende aastate jooksul korduvalt Varssavi kabarees Vainukägu, rääkis joodiku võitlusest kadakaviinaga. Selle peategelast, parandamatut joodikut (kes oli ilmselgelt inimtüüp, keda tolleaegses kommunistlikus Poolas võis ka reaalsuses sageli kohata; vt ka Laineste 2012) mängis tõetruult näitleja Edward Dziewoński. Nagu selgub monoloogi käigus (vt http://www.youtube.com/watch?v=fe8DLOsu6fM), käskis tema naine tal kallata kraanikausist alla kaksteist pudelit kadakaviina. Seda piinarikast käsku täites joob peategelane igast pudelist ära ühe teeklaasitäie ning monoloogi edenedes jääb aina rohkem ja rohkem purju. Ta kirjeldab, kuidas ümbrus muutub häguseks ja maailm hakkab keerlema, kuid samaaegselt jääb tema jutustamisstiil silmapaistvalt peenekoeliseks ja kaunikõlaliseks. Viimase punkti paneb monoloogile tema kõrgelennuline kompliment, mille ta teeb oma naisele. Vastukaaluks sellele rõhutati Tey Cabaret's etenduse spontaansust, mida hinnati rohkem kui teksti kirjanduslikku kvaliteeti. Tõenäoliselt kerges joobes näitlejad rääkisid seal irooniliselt, kõnekeelseid väljendeid kasutades, poliitikast. Näiteks parodeeriti poliitilisi hüüdlauseid (vt http://www.youtube. com/watch?v=f4O1iyJX0_w). Arvata võib, et see spontaansus oli siiski vaid näiline ja tegelikult oli tegu ettevalmistatud materjaliga. Samas oli iga kabareeõhtu erinev, sest publik vaheldus ja esinejad kohandasid end iga kord vastavalt konkreetse publiku ootustele ja reaktsioonile.

Ka raadios pakuti kuulajatele huumorit. Tuntud huumorisaade oli näiteks "60 minut na godzinę" (60 minutit tunnis, saade oli eetris aastail 1974-1981), kus esinesid Elita kabaree näitlejad. Keelekasutus jäi pigem kõnekeelseks, sihiga parodeerida oma kaasaja kombeid ja laialt levinud korruptsiooni (naljateravik oli suunatud ülemuste, aga ka näiteks arstide suunas, mis oli näiteks kuulsa raadiomonoloogi "Noore arsti päevik" teemaks). Väga populaarseks sai ka sketšiseeria, milles viidati patriootilisele triloogiale ("Tule ja mõõgaga", "Uputus" ja "Pan Wołodyjowski") 19. sajandi autori Henryk Sienkiewiczi sulest. 
Raadioeetris kõlas selle satiiriline paroodia nime all "Rycerzy Trzech" (Kolm rüütlit), ning nende sketšide sisu oli üle võetud mainitud romaanidest, kuid väikeste muudatustega: nimelt kaotati kõik viited patriotismile ja aadlikele, ning rõhutati kõike "lubatut" nagu peategelase pahed, argus, joomarlus, ahnus, lõbujanu jm, mis on olemas ka originaalis, kuid mis seal jäi selgelt tagaplaanile. 17. sajandi Poola elu-olusse oli lisatud ka viiteid kommunismiajale, keele poolest jäi esitus enamasti truuks vanaaegsele ja suursugusele väljendusviisile, kuigi sellele lisandus aeg-ajalt kaasaegset kõnekeelt ja idioome. Raadiosaadet "60 minutit tunnis" tuntakse siiani tema tunnuslaulu järgi (vt http://www. youtube.com/watch?v=3jP779Gr41Q). Saate populaarsus ajendas produtsente tegema sellest ka televersiooni, kus 17. sajandi aadlikekostüümides näitlejad parodeerisid originaalteose lennukat kõneviisi (vt http://www.youtube.com/ watch?v=ccx4-KT_ACs\&feature=related).

1989. aasta poliitiline muutus avaldas kabareekultuurile tohutut mõju. Kui enne 1990. aastaid olid kabareed küll aktiivsed, kuid nende eksistents oli tsensuuri pideva valvsa kontrolli all, siis pärast kommunistliku režiimi langust võisid kabareed piiramatult õitseda ja paljuneda. Rahvuslik kabareefestival PAKA (Polska Akademia Kabaretu) sai alguse juba enne poliitilist muutust, aprillis 1985, kuid pärast 1989. aastat võis seda üle kanda ka televisioonis. Aina uued kabareed astusid seal üles ja võitsid, mis omakorda stimuleeris ettevõtlikke inimesi avama uusi kabareesid. Mitmed linnad või maakonnakeskused said tugevateks kabareekultuuri esindajateks, neist omapäraseim on Lääne-Poolas asuv Zielona Góra. Władysław Sikora, kes oli ise kabareenäitleja ja draamaosakonna lektor ühes sealses ülikoolis, rajas selles piirkonnas enam kui tosin uut kabareed, mis said kõik tuntuks üle kogu Poola. Uutes Poola kabareedes sai peamiseks stiiliks sketšide näitlemine ja kabareelaulude esitamine (vt Błąd 2012) ning monolooge tuli ette aina harvem. Kui sketšides peeti kinni ettekirjutatud tekstist, siis improviseeritud etteasteid lubati lavale sketšide vahepeal, kui õhtujuht järgmist esinejat sisse juhatas.

Üldjoontes peab ütlema, et see polnud väga viljakas pinnas, millel võinuks juurduda uus läänelik stand-up sellisel kujul nagu see on levinud Suurbritannias ja Ameerika Ühendriikides.

\section{Stand-up kui žanr}

Enne tänapäevaste Poola stand-upi trendide kirjeldamist peatume hetke kõnealuse žanri definitsioonil ja põhijoontel nagu seda on kirjeldanud uurijad. Oliver Double, kes ka ise on tuntud püstijalakoomik, on kirjutanud sel teemal mitu põhjapanevat tööd. Tema kirjeldab stand-upi kui etendust, kus publiku 
ees seisab üks inimene, kelle esmane eesmärk on inimesi naerma ajada (Double 2005: 19). Kolm põhifaktorit, mis iseloomustavad püstijalakomöödiat on

- isiksus (huumori aluseks on isiksus ja eneseväljendus),

- otsene suhtlus publikuga,

- $\quad$ esitus toimub siin ja praegu (esitussituatsioon on väga oluline).

Püstijalakomöödia oluliseks osaks on esineja identiteedi ambivalents. Publik peab esinejat kuulates pead murdma, kas too räägib enda eest või etendab ta mõnda karakterit (Double 2005: 73). Ka näitlemine ise on stand-up laval erinev draamanäitleja tegevusest: esitatav karakter pole õpitud, jälgitud, esitatud läbinisti tunnetatuna, vaid selles on suur annus improvisatsiooni ja spontaansust, isegi kui seegi on varem teksti planeeritud (Double 2005: 82). Autentsuse ja karakteri rõhutamiseks kasutavad tänapäeva püstijalakoomikud sageli kõnekeelt ja vägisõnu. Tõepärasus ja autentsus ongi Double’i meelest kaks märksõna, mis moodustavad kaasaegse stand-upi keskse kontseptsiooni (Double 2005: 97). Näiliselt spontaanne püstijalakoomik on pidevas suhtluses publikuga, "vahetades energiat" ja reageerides kuulajate olekule, olgu selleks heakskiit, halvakspanu või sootuks reaktsiooni puudumine (Double 2005: 108; samas lisab ka Double, et stand-up toimub siiski defineerimatult ja maagiliseltki, ning artistidel peab olema kaasasündinud lavasoon, mida ei saa õppida ega jäljendada). Esineja peab laval olles panema publiku end tundma ühtsena; publikul peab tekkima side esinejaga, keda tajutakse kui (kultuurilises, etnilises või lingvistilises mõttes) ühte enda hulgast. Sellele eesmärgile aitavad alati kaasa sissejuhatavad laused konkreetse koha ja publiku kohta, millega kuulajad saavad kohe seostuda. Kõige suuremat naudingut pakuvad püstijalakomöödias aga hetked, mis on ehtsad ja spontaansed (Double 2005: 180).

Stand-upi eripäraks ning tunnuseks, mis eristab seda kabareekultuurist, on selle tung mängida publiku taluvuspiiril. Selline reeglite rikkumine on omane üldiselt intellektuaalsele huumorile (vt Kuipers 2006; vt ka Kuipersi raamatu arvustust: Chlopicki 2009). Artistil on selle saavutamiseks mitmeid vahendeid: näiteks võib ta jagada publiku kahte leeri või kõnetada (või pilgata) mõnda inimest isiklikult, pakkuda välja vaatepunkte, mis kuulajaid kindlasti ärritaksid ja mis käiksid nende tõekspidamiste vastu (sest hea koomik ei ole tingimata see, kes meeldib publikule, vaid see, kes paneb nad kaasa mõtlema), sundida publikut muutma oma vaateid, rünnata vahelesegajaid, ja pakkuda publikule sissevaateid temasse kui esinejasse - oma kommetesse, pahedesse, eelistustesse - mis tekitab kuulajates tunde, et nad tunnevad nende ees seisvat inimest hästi.

Stand-up selle praegusel kujul sündis Suurbritannias ja Ameerika Ühendriikides 1960. aastatel vodevilli ja varieteekultuuri mantlipärijana. Selle stiili märksõnadeks sai publiku "tulistamine" järjestikuste naljadega (vs tervikliku 
jutustuse ettekandmine), hääle ja aktsentidega mängimine, karakterite kehastamine (mis Kuipersi uurimuses kuulub labase huumori alla - Kuipers 2006) ja vänge keelekasutus, mis pidi, nagu eelpool öeldud, lisama autentsust ja vahetust.

Stand-up sai Poolas peagi üsna mõjukaks, ning poliitiliste muutuste laineharjal 1990. aastate alguses ja järgneva kümnendi jooksul üritati mitmel moel püstijalakomöödiat publikule lähemale tuua ja seda "kodustada", et elavdada ja uuendada Poola kabareekultuuri kopitanud õhustikku. Esiteks pidid esinejad žanriga tutvuma. See motiveeris avama esimest stand-upi kooli, kus õpetas üks parimaid tolle aja kabareenäitlejaid, Grzegorz Halama.

\section{Poola tänapäevane stand-up ja selle seos kabareekultuuriga}

Avati uued, stand-upile keskenduvad komöödiaklubid nagu Piwnica u Mariana (Kelder Mariani Juures), kus esines näiteks naiskoomik Ela Wycech. Naisena keskendus ta teemadele, mis puudutasid otseselt õrnemat sugupoolt, ja adresseeris oma etteasted eelkõige naissoost kuulajatele (vt http://www.ipla.tv/ Odcinek-6-ela-wycech/vod-5150450). Ka see sai iseloomulikuks komöödia uue laine juures: seninägematult naiseliku teemakäsitluse ja lähenemisnurgaga saavutas Wycech midagi, mis on püstijalakomöödia lahutamatuks tunnuseks: ta mängis publiku taluvuspiiril ja nihutas või laiendas seda. Tema etteastetes on kindel koht ka enesepaljastuslikel avaldustel, Wycechi enesekriitilised naljad kehakaalu ja ilu aadressil on midagi, mida me tema Lääne kolleegide repertuaaristki palju leiame (nt Joan Rivers, vt ka Lockyer 2011; samuti võiks lugejale siinkohal huvi pakkuda naiste enesekohasest huumorist kui strateegiast kõnelevad uurimused, nt Gray 1994, Horowitz 1997).

Ka mehed, kes stand-up laval esinevad, kasutavad sageli enesekohaseid väiteid; näiteks Cezary Jurkiewicz pakub publikule sageli peamurdmist, kas need piinlikud detailid tema eraelust käivad tõesti nende ees seisva inimese kohta või pigem karakteri kohta, keda ta kehastab. Pidev mitmetimõistetavus paneb publiku proovile, ning reaktsioonid vahelduvad kahjutundest kahjurõõmuni. Jurkiewicz keskendub enamasti kolmele teemale: seksile, narkootikumidele ja usule. Näiteks ühes oma etteastes alustab ta nalja nii:

Just möödus minu üksielamise kuues aastapäev. Üksikutel inimestel on teised prioriteedid. Minu jaoks on kõige olulisem see, et mul on erootilised unenäod. Mul just hiljuti oli üks eriti hea erootiline unenägu. Ma nägin oma ema, ja ema küsis, mida ma hommikusöögiks tahaksin. Ma ütlesin: 
"Pask!" Ja ma tean, et mu ema teeb alati seda, mida ma temalt palun. (vt http://www.youtube.com/watch?v=aE1TBDl-rxk)

Krzysztof Unrug, teine tuntud püstijalakoomik, alustab ühte oma esinemist seeriaga naljadest, mille eesmärk on proovida järele, mis publikule "peale läheb", valmistada neid ette ja suurendada nende valmisolekut naermiseks:

Jeesus, mingi põrandalamp [kommentaar lavakujunduse kohta]. Tere tulemast. Et te... et te olete siia tulnud. Jumal, kui hele valgus siin on. Valgustatus. Tere tulemast siia ilusasti kaunistatud ruumi, siin on nagu stseen Witkacy etendusest "Szewcy"1. Ššššs. Õlu ja muusika, teate, selline õhustik... Minu nimi on Krzysztof Unrug. Mu ema ütleb, et ma olen täpselt nagu minu Honda: väike, lärmakas ja joon palju [nõrk naer]. No kuulge, see on tasuta õhtu. See oli ju naljakas. (vt http://www.youtube. com/watch?v=esc7UvxDhGA\&feature =related)

Hiljem laskub ta veelgi enam enesepaljastustesse, arendades veidi gei-teemalist naljaliini:

Ma käisin hiljuti Parada Równościl [võrdsusparaad, so geiparaadil], nii et nü̈̈d te teate minust veel midagi. See läheb aina paremaks ja paremaks. Nii et see oli võrdsuse paraad. Aga miks võrdsuse, minu meelest oli see rohkem erinevuste paraad, või mitmekesisuse paraad. Keegi kunagi pani vale nime ja nü̈̈d ei saa sellest enam lahti. Niisiis, ma olin sellel paraadil ja ma oleks tõesti pidanud vist õhupüssi kaasa võtma [nõrk naer]. No kuidas muidu sa linde kätte saad? Kõik need suled... nendel inimestel olid kindla peale kakaduu geenid. Kui sa saadaksid nad Uus-Guineale, siis kakaduud kõik imestaksid: "Oh, kurat, vaata, mutandid!" [naer]

Viimane kujund lõbustab publikut. Siin on näha, kuidas esineja kasutab nii piiride avardamise kui ka näilise enesepaljastuse tehnikat, et publikuga ühendust saada, ja tema etteaste koosneb pigem lühinaljade seeriast kui ühest koherentsest jutustusest.

Poola stand-up on vahel ingliskeelne, kuigi esitajateks on poola artistid. See on tavapärane näiteks Varssavi rahvusvahelises Comedy Clubis. Sealsed teemad keerlevad enese pihta suunatud naljade ja peldikuhuumori ümber. Viimane pole aga varem poola humoristikas kuigi sagedane olnud. Näiteks kuulub peldikuhuumor selles klubis esineva koomiku Not So Super Mario püsirepertuaari. Etteaste algab tavaliselt tema ja klubibändi kerge kemplusega, kus ansambel lõpetab oma vahepala liiga hilja, mis takistab Not So Super Mariol õigel ajal alustamist, ning sellises teineteisest möödarääkimise õhustikus hakkab bänd just alati siis mängima, kui esineja suu lahti teeb. Pärast mõningaid mitteverbaalseid nalju saab esineja lõpuks sõna. Ta esitleb end kui 
"grupi kõige paksem liige. Ja tegelikult olen ma ainus mees siin, kes pole briti, ameerika, austraalia, või mis kuradi juurtega." - "Me armastame sind ikka, mees," kommenteerib keegi publikust. Siis teeb ta tüüpilise peldikuhuumori näite: "Minuga juhtus täna naljakas asi. Ma läksin Varssavi Złote Tarasy vetsu ja pissuaari kohal oli naljakas kleeps: "Sa hoiad tervet maailma oma käes." Milline kuradi väike maailm, mõtlesin mina” [naer]. Sellele järgneb üsna pikk lõik, kus ta kirjeldab oma probleemi, mis tal on seoses avalikus kohas urineerimisega. Ta toob näite, kuidas ükskord seisis tema kõrval vanamees, kes tegi veidraid hääli, mis teda häda toimetamisel segasid, või teine kord, kui ta kuulis kedagi kõrvalkabiinis masturbeerimas. Tema kuulajaskond ignoreerib teda, kuigi üldiselt on nad abivalmid ja isegi abistasid teda, kui ta ei teadnud ingliskeelset terminit pissuaari kohta. Aga üldiselt on selge, et tema etteaste püsib peamiselt obstsöönsetel teemadel ja peldikuhuumoril (vt http://www. youtube.com/watch?v=eXKFG-2XU7s\&feature=related).

Poola püstijalakomöödias leidub ka veidi teisetoonilisi esinejaid. Nende etteasted on rohkem struktureeritud ja neis on vähem agressiivset keelekasutust. Rafał Rutkowski, kes esineb HBO Comedy Clubi telesaates, proovib enamasti teha publikuga seda, mida Oliver Double nimetas "üksmeele leidmiseks" (shifting consensus), st tema eesmärgiks on publiku mõttemalli muutmine. Tema meelisteemadeks on seks ja sõnamängud. Ühes etteastes, kus õhtujuht on ta just lavale kutsunud, alustab ta üsna äkiliselt:

Kuulge, ma tahaksin tagasi tulla ühe teema juurde, millest siin juba rä̈̈giti. Kes teist "kultiveerib” seksi [idioom poola keeles, 'uprawiać seks']? Ei, see ei olnud mõeldud naljana, tõsiselt. Oo, braavo, härra. Keegi veel? Aga mina ei kultiveeri seksi, sest ma pole maalt. Ja kujutate ette, seks on alati olnud midagi, mis tõstab meid kõrgustesse, annab meile tiivad, ja meie siin räägime seksist nagu see oleks mingi peet. [Kujutab karakterit] "Tere, minu nimi on Zenek, ma olen ametilt peedikasvataja." - "Tere, minu nimi on Angela, minu amet on seksi kultiveerimine." - "Tore! Kui oled huvitatud, siis tule meie juurde maale, meil on mõned tüdrukud, kes teavad kultiveerimisest kõike." - "Kas kultiveeriksime midagi koos?" - "Jah, aga tead, Angela, sa pead midagi pikemat selga panema, sest päike võib su häbeme niimoodi ära kõrvetada” ['bo ci słońce pizdę zjara' - vulgaarne slängiväljend].

Tema etteastel on hoomatav struktuur, kuid puänt tundub valmistavat meelepaha, eriti mõnele publiku naissoost liikmele, kes videoklipil kaadris paistavad. Mehi ei paista puändi rämedus häirivat (vt http://www.youtube.com/ watch?v=BH-MB0loIUs). 
Abelard Giza on koomik, kes kasutab oma etteastetes mitteverbaalset huumorit ja osutab materjali otsides sageli oma veidi kesk-aasialikule välimusele, mis tundub üsnagi edukas valik. Ühte sketši alustab ta järgmiselt:

Mul on hea meel, et me pole väliüritusel. Sest väliüritustel teevad inimesed nii [kortsutab kulmu], ja siis ma ei saa aru, kas neile ei meeldi minu etteaste või neile paistab lihtsalt päike silma. Kuulge, kui ma ennist lavale tulin, siis vean kihla, et pooled teist mõtlesid: jah, tahaks üht kebabi. Jah, ma tean seda. Ja teine pool mõtles: kas pomm tema särgi all purustab terve hoone või ainult kolm esimest rida. Teate, ma ütlen teile, see polegi pomm. See on minu kõht, mis on viimasel ajal kontrolli alt väljunud ja elab oma iseseisvat elu. (vt http://www.youtube.com/watch?v=gN7Zy9OXpN4)

Tema teemadeks on etniline kuuluvus, terrorism ja narkootikumid, millele ta läheneb enesepaljastuslike avalduste kaudu.

Tunnustatud Poola kabareeartistid on jõudnud õigustatud järeldusele, et stand-upi lavale tuleb otsida uusi talente. See arusaamine pani aluse võistlusele, mille pealkirjaks sai "Zabij mnie śmiechem" (Naeruta mind surnuks). Võistluse finalistide etteasteid näidatakse ka televisioonis. Üks varasem võitja, Mariusz Kemp, sai võidu tänu oskuslikule karakterikasutusele: ta esitles oma isikupära (või õigemini mitte-isikupära), milleks on monotoonne ja emotsioonivaba hääl ja olek, rääkides nalju (või pigem mitte-nalju, st tehes absurdi kalduvaid avaldusi). Tema viimane etteaste algab sõnadega "Tere õhtust," mille järel ta hakkab laval ringi kõndima, seletades, et see aitab tal lõdvestuda. Siis jätkab ta saalimist, ja lõpuks peatub, öeldes: "Ei, ma vist olen juba liiga palju kõndinud." Ta läheb edasi enese pihta suunatud naljadega, mida ta esitab oma iseloomulikul monotoonsel, kergelt väriseval häälel:

Mina kui tuntud mõistetamatu ja viletsa huumoriavangardi esindaja oman laval mõningaid veidrusi. Näiteks hoian ma vahel üht kätt kannikal. Või siis on mul käbi taskus [võtab selle välja ja näitab publikule], või siis küpsis [võtab välja ja pistab suhu].

Siis keskendub ta oma etteaste suurimale veidrusele ja lõpetab rääkimise sootuks, ning näitab publikule ükshaaval suuri valgeid pabereid, millele on midagi peale kirjutatud: "Vaikus", "Suurepärased valged kaardid, avangardi Himaalaja”, "Jah", "Tumm stand-upi tüüp”, "Esimene Poolas", "Teine maailmas", "Kohe pärast ungarlasi", "See on stand-up argadele" (vt. http://www.dailymotion.com/ video/xfqdnv_michay-kempa-zabij-mnie-ymiechem-odc-8-finay_fun). Kuigi see etteaste vastab stand-upi standarditele (vahetus, autentsus, kõnekeelsed väljendid, enesepaljastus), on selles ka kabareekultuuri jooni (monoloogilisus, põhjalikult ettevalmistatud sketš). 
Võttes arvesse kõiki ülaltoodud näiteid võime öelda, et nii mõnedki standupis läbi löönud artistid kasutavad ära kabareekultuuri parimaid külgi. Edasi vaatleme mõningaid näitlejaid, kelle repertuaaris on tunda rohkem kabareeelemente. Esimesena tuleb mainida tuntud miimi Ireneusz Krosnyt, kes on stand-upiga hakanud tegelema suhteliselt hiljuti. Üks ere näide tema stiilist on laulude "illustreerimine" liigutuste abil. Sõna-sõnalt võetavate või tekstiga seostuvate / vastuollu minevate žestidega loob ta (näitena toodud videos laulja nimega Feel laulule) justkui sõnadeta tõlke (vt http://www.youtube.com/ watch?v=UFNY_mbALWQ). Selline paroodiavorm võtab sihtmärgiks sisutühjad sõnad, mis poplauludel nii sageli on. Samal ajal on Ireneusz Krosny lähenemine väga omapärane ja ekspressiivne, mis loob ka tugeva põhja tema lavaisiksusele.

Intelligentne õhtujuht, eduka meelelahutusõhtu peaaegu olulisim osa, kuulub ka järjepideva kabareetraditsiooni juurde. Oma särava isiksusega on selle raske töö endale võtnud viimaste aastakümnete edukaim huumoriõhtute teadustaja Piotr Bałtroczyk, kes on ka ise kabareedes näitlejana üles astunud. Ta ei kasuta enese pihta suunatud huumorit, vaid sageli hoopis kiidab ennast mõõdutundetult (ja irooniliselt). Üks tema etteastetest külalisena võistluses "Naeruta mind surnuks" algab paari sissejuhatava lausega, ja jätkub siis nii:

See ainuke, unikaalne, see, kelle kena väljanägemine paneb ka kauneimad meie seast nutma, tema, Warmia [regioon Kirde-Poolas] kuulsus, Warmia farmer, tema, kellest te olete kõige rohkem puudust tundnud-Piotr Battroczyk. Tere õhtust. Tere tulemast siia konditsioneeritud õhuga ruumi [naer]. On tõesti tore olla selle teatri laval, Juudi teatri laval [Varssavis], sest just siin tegi Jerzy Kryszak [üks žüriiliikmetest, kes etteastet parajasti kuulab] oma debü̈̈di aastaid tagasi. Siis olid tal samasugused juuksed peas [Kryszak on tuntud oma Einsteini soengu poolest], aga vuntse tal veel polnud, ja ta mängis väikest juudi tüdrukut, kellel oli käes üks tuletikk: ainult üks tuletikk, sest tema perekond oli lihtsalt nii vaene. (vt http://www.youtube.com/watch?v=5VMTvfnM9NI)

Stand-upi vahetus ja autentsus on ka siin olemas, ja Bałtroczyki etteaste tundub tõesti spontaanne. Ta valib välja ühe inimese (žüriiliikme) ning hakkab tema üle nalja heitma, võites seeläbi publiku enda poole. Tema esinemised on alati pisiasjadeni ette valmistatud, ükskõik kui lühikesed need ka poleks.

Robert Górski kuulub kabareetruppi nimega Kabaret Moralnego Niepokoju (Moraalse Ärevuse Kabaree), mis on viimase 20 aasta populaarsemaid koosseise. Nende algne idee ja juhtmõte oli võidelda stereotüüpide vastu. Kõik truppi kuuluvad näitlejad on oma alal edukad, ja sageli astuvad nad ka kabareeõhtutel ette karakterite impersonatsiooniga. Nad etendavad ka monolooge. Ühes neist (vt http://www.youtube.com/watch?v=u9JLvX_iTyw) kehastab Robert Górski 
töölisklassi meest, üsna edukat autovarast, kes on ühtlasi väga patriootiline spordisõber. Teel Saksamaalt tagasi peatub ta koos sõbraga suusahüppevõistluste toimumispaigas, et toetada Poola tšempioni Adam Małyszit. Et neil pole pileteid, hakkavad nad kaevama tunnelit aia alt läbi. Siis aga kukub kaevatud auku üks möödaminev suusahüppaja, autovaras ja tema sõber võtavad tema riided ja suusad ning lähevad sisse, üks neist suusahüppajaks riietatuna ja teine tema treenerina. Treener ei viida aega ja hakkab kohe pealtvaatajate hulgas autodega kauplema, samal ajal kui sõber on sunnitud hüppama ja juhuslikult võidab võistlused, saades kristallkarika uhkeks omanikuks. Sellega koju minema hakates kukub ta auku, mille nad alguses kaevanud olid, ja murrab oma jalad. See füüsilise huumori poolest rikas jutustus töötab monoloogina, suuresti tänu Górski näitlejameisterlikkusele.

Viimaseks näiteks on monoloog, mille autoriks on professionaalne koomik Cezary Pazura, tuntud näitleja filmides, komöödiaseriaalides ja telesaadetes. Ühes oma etteastes räägib ta tervisest ja apteegikaupade reklaamist (vt http:// www.youtube.com/watch?v=yS48rVKVnqw\&feature=related). Ta alustab lühidalt seltskondliku vestluse stiilis:

Kuidas läheb? Kõik korras? Ilm on suurepärane. Vist. Ma ei ole ammu väljas käinud. Nad lukustasid mu siia, nii et siin ma nü̈̈d olen. Rahunege. Ma ei küsi teie tervise kohta, sest ma ei usu haigustesse. Haigusi pole olemas. See on suur vandenõu. Nemad, nemad, reklaamivad ravimeid televisioonis ja räägivad meid niimoodi pehmeks, et me hakkaksime uskuma haigusi. Ja nii ka, et me usuksime sümptomeid, et me hakkaksime ostma nende tablette: köha, tilkuv nina, põskkoopapõletik, eesnääre...

Ta esitab ettevalmistatud monoloogi nii, et tema tegelaskuju tundub väga usutav.

\section{Lõpetuseks}

Kabareetraditsioon, mis kunagi oli Poolas väga populaarne, pole tänapäevalgi ligitõmbavust kaotanud. Igal juhul tundub see olevat elujõulisem kui puhas sissetootud stand-up, mida viljeletakse komöödiaklubides, sh ingliskeelsena. Viimast esitavad amatöörid, kes kasutavad sageli enese pihta suunatud huumorit, tehes seda üksikute naljade jadas, mis ei moodusta koherentset lugu, ja mis pole vahel üldse naljakad. Seevastu kabaree-juurtega näitlejad kasutavad pigem oma näitlejameisterlikkust, kehastavad karaktereid ja esitavad sidusaid narratiive, millega publik haakub. Publik on juba harjunud kabareedest tuntud etteastetega - sketšid, laulud, monoloogid - mida võib leida ka tänapäeval, 
nt ülaltoodud suusahüppaja-sketši puhul, mida esitas Robert Górski. Hästi struktureeritud peened intellektuaalsed etteasted on poola publiku silmis paremas seisus kui hüpliku ülesehitusega ohtrate obstsöönsustega vürtsitatud püstijalakomöödia.

Tuleb rõhutada kabareekultuuri neid põhijooni, mis siiamaani võidavad enda poole publiku ja moodustavad omaette žanri stand-upi sees. Nende etteastete edu tagavad autentsus (näiline spontaansus, idioomid ja rikkalik keelekasutus), lavapersooni sarm, identiteetide paljusus (kus esineja on ka tuntud näitleja, kuulsus või muul moel tuntud tegelane, keda publik on näinud teistes rollides), kehastumis- ja jutustamisoskus (mille puhul on kasu lavalisest haridusest), publiku kaasahaaramisvõime ning julgus kõndida piiridel, nihutades neid aina kaugemale taluvuspiirist, ning vaatepunkti värskus (nt kehastades laval bakterit).

Kriitika, mis kabareetraditsioonist rääkides läbi jookseb, on suunatud eelkõige selle kommertsialiseerumise pihta: esinejad lasevad lati alla, et kommertsmeedia vajadustega kaasa minna. Kabareeõhtute ülekanded televisioonis on küll populaarsed, kuid samal ajal vähendab see koomikute esinemisvabadust, muudab huumori lihtsaks ja kergestimõistetavaks, ning kaugeneb seega algsest kirjandusliku huumori traditsioonist. Spontaansuse ja autentsuse õhkkond on kabaree jaoks eluliselt tähtis, ja kuigi poola publik on rahul ettevalmistatud esinemistega, pakuvad mõned uued trendid ka täiesti autentset kohapeal improviseeritud püstijalakomöödiat. Näiteks võib tuua tudengiklubides korraldatavad improvisatsiooniõhtud, kus teema määrab publik. Nemad mõtlevad kohapeal välja mõne suuna, ja etlejad peavad end proovile panema ning märksõnadele toetudes improviseerima humoorika etenduse. See on nö rühma-stand-up, kus loeb kiire mõistus ja intelligents, ja kus võivad esineda skatoloogilised või seksuaalsed viited, kuid need ei ole mingil juhul etenduse põhiline või defineeriv osa. Kui noored koomikud seda suunda jätkavad, võib see aja jooksul panna aluse positiivsemale tulevikunägemusele praegusest "traagilisest" püstijalakomöödiast. Ühtlasi tähendaks see tagasipööret spontaanse, dekadentliku, kuid peenetajulise kabareekultuuri juurte juurde, mida esindas kunagi Väike Roheline Õhupall.

Tõlkinud Liisi Laineste

\section{Kommentaar}

1 "Kingsepad". Stanislaw Ignacy Witkacy oli 20. sajandi alguses tuntud poola poeet, näitekirjanik, kunstnik. 


\section{Kirjandus}

Błąd, Łukasz 2012. Cabaret in Poland. Brzozowska, Dorota \& Chłopicki, Władysław (toim). Polish Humour. Kraków: Tertium, lk 175-220.

Chłopicki, Władysław 2009. Paul Simpson, On the discourse of satire: Towards a stylistic model of satirical humour. Amsterdam, Philadelphia: John Benjamins, 2003; Giselinde Kuipers, Good Humor, Bad Taste: A Sociology of the Joke. Berlin, New York: Mouton de Gruyter, 2006. Raamatuarvustused. Journal of Pragmatics 41, lk 857-862.

Double, Oliver 2005. Getting the joke: The Art of Stand-up Comedy. London: Methuen.

Kiec, Izolda 2004. W kabarecie [Kabaree]. Wrocław: Wydawnictwo Dolnośląskie.

Kuipers, Giselinde 2006. Good humor, bad taste. A sociology of the joke. Berlin \& New York: Mouton de Gruyter.

Laineste, Liisi 2012. Stand-up in Estonia: From Soviet estrada to Comedy Estonia. Laineste, Liisi \& Brzozowska, Dorota \& Chłopiki, Władysław (toim). Estonia and Poland: Creativity and tradition in cultural communication 1: Jokes and their relations. Tartu: ELM Scholarly Press, lk 73-90.

Lockyer, Sharon 2011. From toothpick legs to dropping vaginas: Gender and sexuality in Joan Rivers' stand-up comedy performance. Comedy Studies 2: 2, lk 113-123 (doi:10.1386/cost.2.2.113_1).

Lockyer, Sharon \& Lynn Myers 2011. 'It's about expecting the unexpected': Live standup comedy from the audiences' perspective. Participations: Journal of Audience and Reception Studies 8 (2), lk 165-188.

Wojtak, Maria 2012. Comic effects in the stage works of Aleksander Fredro (tõlk. W. Chłopicki). Brzozowska, Dorota \& Chłopicki, Władysław (toim). Polish Humour. Kraków: Tertium, lk 57-78.

\section{Summary}

\section{The uneven struggle of stand-up in Poland with the cabaret tradition}

\section{Władysław Chłopicki}

Keywords: cabaret, monologue, Polish humour, stand-up

The article first describes the old cabaret tradition of Polish comedy, and then looks at various forms of stand-up that have been spreading in Poland over the last 20 years, mainly on TV, but some originating in newly established comedy clubs. Within the last twenty years, the new form of stand-up in its American variety has been slowly moving in. The characteristics of this new genre included precisely the topics which were excluded from the old form (such as explicit sex references and scatology) as well as the focus on the vernacular. The common features of stand-up included immediacy, playing 
cultural and linguistic kinship with the audience, impersonations, "shifting consensus", seeming spontaneity, and occasional self-deprecation. Young performers found a venue in the well known HBO show called "Na stojaka" (an attempt to translate stand-up into Polish, a show which ran for ten years), as well as other venues such as the stand-up competition called "Zabij mnie śmiechem" ("Kill me with laughter") broadcast by the Polsat commercial channel since 2010, in which the winner is rewarded with a trip to an American stand-up school.

This kind of stand-up does not meet with universal appeal, as one comment found on the internet clearly shows: "Stand-up Tragedy". The Polish audiences largely believe that the performance must be first of all funny, and only then "authentic", while some young performers seem to play mainly on obscenity and scatology and forget the need to amuse. Therefore, even though the new form has been slowly gaining ground, the cabaret prevails both in some of the forms which it shares with stand-up (e.g. non-interactive monologues, which are no longer literary but colloquial, or impersonations) and also with regard to popular performers, who largely originate in cabaret or are well-known actors. 